\title{
Distinguishing the Protected Designation of Origin Apricot (Prunus armeniaca L. cv. Şalak) from Closely Related Cultivars by High Resolution Melting
}

\author{
Kaan HÜRKAN
}

I $\breve{g} d ı r$ University, Faculty of Agriculture, Department of Agricultural Biotechnology, I $\breve{g} d t r$, Turkey ORCID ID: Kaan Hürkan: https:// orcid.org/0000-0001-5330-7442

\begin{abstract}
Received: 05.03 .2021
Accepted: 11.09 .2021

Published online: 01.10 .2021

Issue published: 31.12 .2021

Abstract: The apricot cultivar Prunus armeniaca cv. Şalak (registered as "Iğdır Kayısısı") is a Protected Designation of Origin (PDO) apricot and produced in Aras Basin (Iğdır, Turkey) region. Authenticating the special products, which has adulteration potential, by DNA based methods is reliable and cost-effective. The aim of the current study is to distinguish the PDO apricot from closely related cultivars by High Resolution Melting. We tested 12 SSR markers previously validated for Prunus spp. by means of distinguishing the ability of five closely related apricot cultivars that are Şalak (AS), Hasanbey (HB), Hacıhaliloğlu $(\mathrm{HH})$, Kabaaşı (KB), and Şekerpare (SK) produced in Turkey. Capillary electrophoresis validation showed 11 of 12 markers amplified unique fragments for the cultivars. HRM analysis combined with the Principal Component Analysis (PCA) successfully distinguished the PDO AS from closely related cultivars. HRM analysis combined with PCA can be a cost-effective and reliable authenticating method for PDO food products.
\end{abstract}

Keywords: Genotyping, microsatellites, authenticity, food adulteration, SSR-HRM.

\section{Coğrafi İşarete Sahip Şalak Kayısı Çeşidinin (Prunus armeniaca L. cv. Şalak) Yakın İlişkili Çeşitlerde Yüksek Çözünürlüklü Erime Yöntemi ile Ayırt Edilmesi}

\begin{abstract}
Öz: Şalak kayısı çeşidi (Prunus armeniaca cv. Şalak) Aras Havzası'nda üretimi yapılan ve coğrafi işarete sahip bir kayısı çeşididir. Tescilli ismi Iğdır Kayısısı olarak belirlenmiştir. Özellikle gıda aldatmacasına maruz kalma potansiyeli olan özel gıda ürünlerinin DNA temelli yöntemler ile tanımlanması güvenilir ve görece ucuz maliyetlidir. Bu çalışmanın amacı Şalak kayısı çeşidinin, yakın ilişkili kayısı çeşitlerden Yüksek Çözünürlüklü Erime (HRM) yöntemi kullanarak ayırt edilmesi için bir protokol geliştirmektir. Çalışmada, daha önceden Prunus türleri için doğrulanmış 12 adet SSR belirtecinin, Türkiye'de üretimi yapılan Şalak (AS), Hasanbey (HB), Hacıhaliloğlu (HH), Kabaaşı (KB) ve Şekerpare (SK) kayısı çeşitlerini ayırt etme başarısı test edilmiştir. Çalışmada ayrıca HRM verilerinden Temel Bileşenler Analizi yapılabilmesi için R yazılımında kullanılabilecek bir komut dosyası oluşturulmuştur. Kılcal elektroforez ile doğrulanmış 12 SSR belirtecinden 11 tanesinin, her kayısı çeşidi için farklı fragmentler çoğalttığı tespit edilmiştir. Temel Bileşenler Analizi ile desteklenmiş HRM sonuçlarının Şalak kayısı çeşidini diğer çeşitlerden başarılı bir şekilde ayırt ettiği belirlenmiştir.
\end{abstract}

Anahtar kelimeler: Genotipleme, mikrosatelitler, genetik doğrulama, gida aldatmacası, SSR-HRM.

\section{Introduction}

Apricot is an important drupe fruit and it has been cultivated in Asia since 2000 BC. The plant is cultivated in warm to subtropical regions throughout the world. Prunus armeniaca L. is the commonly cultivated apricot species and thousands of genotypes are cultivated. Turkey is the leading country in apricot production with 677,000 tons of average production (FAOSTAT, 2020). With this production capability, Turkey supplies approximately $20 \%$ of the world's total apricot production. In Turkey, apricot production is specialized in Malatya, Erzincan, and Iğdır regions (Ercişli, 2004). According to the Turkish Statistical Institute 2019 data, Malatya province is leading the apricot production with 391,000 tons in Turkey (Fig. 1) (TÜiK, 2020). Turkey has 28 registered apricot cultivars (Turkish Apricot Research Institute, 2019) and numerous genotypes. Iğdır is also an important province for apricot production. P. armeniaca cv. Şalak, which is cultivated in Iğdır province is awarded the mark of Protected Designation of Origin (PDO) and named as "Iğdır
Kayısısı" (Iğdır Apricot) by the Turkish Patent and Trademark Office (Registration number 385, dated 17 September 2018).

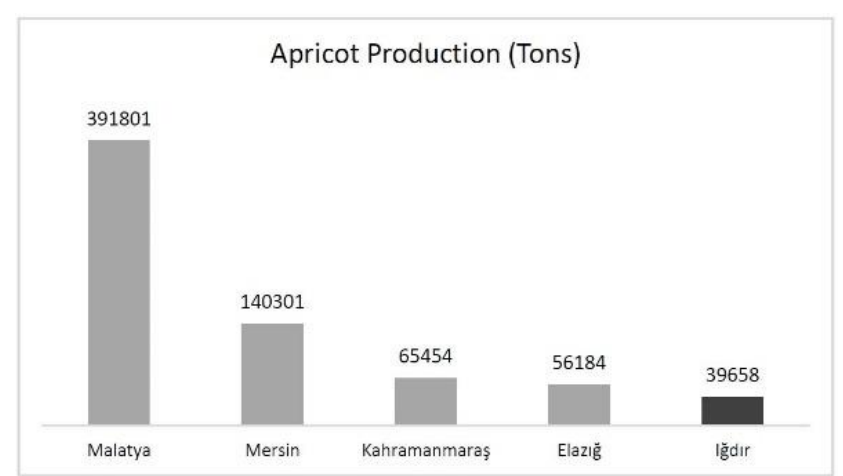

Figure 1. Top five apricot producing regions in Turkey for the 2019 year (TÜiK, 2020).

The PDO products have higher economic value than the non-PDO ones due to their relatively smaller 
production scale and harder production processes, globally. Therefore, it is necessary to ensure that consumers trust PDO authenticity. This causes the emergence of the "traceability of $\mathrm{PDO}^{\prime}$ term. The quantitative traceability of PDO originated food products are important for consumer's protection against food adulteration.

DNA-level tracing of authenticity is quite reliable since it is a stable macromolecule and exists in each tissue and organs and not affected by environmental factors ( $\mathrm{Li}$ et al., 2018). There are various molecular methods that have the capability of traceability of PDO products such as DNA barcoding, SSR genotyping, and etc. Nevertheless, due to both having specialized downstream processes needed (i.e. bioinformatics skills and computing skills) and being relatively expensive, cheaper and faster methods are needed. High Resolution Melting (HRM) is a technique based on monitoring the DNA denaturation and quantification by a Real-Time PCR instrument. Its advantages can be listed as being cost-effective, having high throughput, requiring less laboratory duty, and no complicated software knowledge needed compared to other marker methods. Another advantage of HRM is detecting the sequence variation without sequencing or hybridization processes (Tindall et al., 2009). Either microsatellite markers or barcoding regions have been employed for HRM analysis successfully (Druml \& Cichna-Markl, 2014). HRM was successfully applied to the detection of herbal medicine products (Li et al., 2018), genotyping of peach genotypes (Chou et al., 2020), authenticity testing of sweet cherry products (Ganopoulos et al., 2011), and species identification of ginseng (Osathanunkul \& Madesis, 2019). In a previous study, researchers developed novel HRM markers to detect plum pox virus (PPV) resistance by targeting PPV resistance locus in Prunus armeniaca. According to the results, PPV resistance locus could be detected by using a reliable and user-friendly method HRM (Passaro et al., 2017).

This study aims to develop an HRM based protocol, which distinguishes the PDO Şalak cultivar from closely related cultivars, and validate the Şalak at the cultivar level.

\section{Material and Methods}

\subsection{Plant materials and DNA extraction}

In this study, we chose closely related Turkish apricot cultivars Şalak (AS), Hasanbey (HB), Hacıhaliloğlu (HH), Kabaaşı (KB), and Şekerpare (SK). According to the information we obtained from the local community and Apricot Research Institute authority, those cultivars are rather close in terms of morphology and taste. Therefore, we would like to test the HRM performance on those cultivars. We obtained AS, $\mathrm{HB}, \mathrm{HH}, \mathrm{KB}$, and SK cultivars from the Republic of Turkey Ministry of Agriculture and Forestry Apricot Research Institute (Malatya, Turkey).

We extracted total DNA from $100 \mathrm{mg}$ leaf tissue of the samples using the modified CTAB protocol as described in the literature (Aydin et al., 2018). We confirmed the DNA concentration and integrity by NanoDrop (Maestrogen) and agarose gel electrophoresis and stored the DNA samples at $-20^{\circ} \mathrm{C}$.

\subsection{Primers mining}

Twelve sets of SSR markers that were previously validated for apricot were chosen (Table 1), and checked the amplification success and optimized the PCR conditions for all the primers on each apricot cultivar. The optimum PCR reaction was carried out in a total volume of $20 \mu \mathrm{l}$ containing 2X Reaction Buffer (Thermo Scientific, USA), $0.1 \mathrm{mM}$ dNTPs, $0.2 \mu \mathrm{M}$ both primers, $1 \mathrm{U}$ Taq DNA polymerase (Thermo Scientific, USA), $1 \mathrm{mM} \mathrm{Mg}^{+2}, 10 \mathrm{ng}$ total DNA and nuclease-free water. Thermal cycling (Sensoquest Labcycler Gradient, Germany) condition was $95^{\circ} \mathrm{C} 3 \mathrm{~min}$ first denaturation, 35 cycles of $95^{\circ} \mathrm{C} 30 \mathrm{~s}$ denaturation, $55^{\circ} \mathrm{C} 30 \mathrm{~s}$ annealing, $72^{\circ} \mathrm{C} 1 \mathrm{~min}$ extension, and thermal cycling was finalized by $72^{\circ} \mathrm{C} 10 \mathrm{~min}$ extension step. PCR products were validated by capillary electrophoresis (CE) (Qiaxcel Advanced, Germany) with QIAxcel DNA High Resolution Kit (Qiagen, Germany). The software settings were used as follows; Process profile: Default High Res v2.0; Method: 0H1200; Size marker: GeneRuler 100bp Plus, Thermo, USA (run by side the samples); Alignment marker: QX 15bp-3kb. The results were visualized and analyzed by the ScreenGel 1.2 software.

Table 1. SSR primers used in the study and specifications. Lower / Upper limits are starting and ending points of melting which is filtered for PCA analysis in the R script.

\begin{tabular}{|c|c|c|c|c|c|c|}
\hline Primer & Sequence (Forward and Reverse, $5^{\prime} \rightarrow 3^{\prime}$ ) & $\begin{array}{c}\text { Melting } \\
\text { Temperature }\end{array}$ & $\begin{array}{l}\text { Temperature } \\
\text { Principal Cor } \\
\text { Lower Limit }\end{array}$ & $\begin{array}{l}\text { timization for } \\
\text { nent Analysis } \\
\text { Upper Limit }\end{array}$ & $\begin{array}{l}\text { Expected } \\
\text { Size (bp) }\end{array}$ & Reference \\
\hline pchgms1 & $\begin{array}{l}\text { GGGTAAATATGCCCATTGTGCAATC } \\
\text { GGATCATTGAACTACGTCAATCCTC }\end{array}$ & $55^{\circ} \mathrm{C}$ & 71.22 & 78.39 & $\sim 194$ & Sosinski et al., 2000 \\
\hline pchgms 2 & $\begin{array}{l}\text { GTCAATGAGTTCAGTGTCTACACTC } \\
\text { AATCATAACATCATTCAGCCACTGC }\end{array}$ & $55^{\circ} \mathrm{C}$ & 72.93 & 79.42 & $\sim 163$ & \\
\hline pchgms4 & $\begin{array}{l}\text { ATCTTCACAACCCTAATGTC } \\
\text { GTGGAGGCAAAAGACTTCAAT }\end{array}$ & $55^{\circ} \mathrm{C}$ & 73.16 & 80.71 & $\sim 174$ & \\
\hline UDP96-001 & $\begin{array}{l}\text { AGTTTGATTTTCTGATGCATCC } \\
\text { TGCCATAAGGACCGGTATGT }\end{array}$ & $57^{\circ} \mathrm{C}$ & 76.92 & 82.7 & $\sim 120$ & Cipriani et al., 1999 \\
\hline UDP96-003 & $\begin{array}{l}\text { TTGCTCAAAAGTGTCGTTGC } \\
\text { ACACGTAGTGCAACACTGGC }\end{array}$ & $57^{\circ} \mathrm{C}$ & 76.92 & 82.7 & $\sim 143$ & \\
\hline UDP96-005 & $\begin{array}{l}\text { GTAACGCTCGCTACCACAAA } \\
\text { CCTGCATATCACCACCCAG }\end{array}$ & $57^{\circ} \mathrm{C}$ & 76.92 & 82.7 & $\sim 155$ & \\
\hline UDP96-010 & $\begin{array}{l}\text { CCCATGTGTGTCCACATCTC } \\
\text { TTGATGATTCCATGCGTCTC }\end{array}$ & $57^{\circ} \mathrm{C}$ & 78.53 & 82.13 & $\sim 131$ & \\
\hline UDP97-402 & $\begin{array}{l}\text { TCCCATAACCAAAAAAAACACC } \\
\text { TGGAGAAGGGTGGGTACTTG }\end{array}$ & $57^{\circ} \mathrm{C}$ & 71.17 & 75.49 & $\sim 136$ & \\
\hline UDP98-406 & $\begin{array}{l}\text { TCGGAAACTGGTAGTATGAACAGA } \\
\text { ATGGGTCGTATGCACAGTCA }\end{array}$ & $57^{\circ} \mathrm{C}$ & 72.41 & 79.69 & $\sim 101$ & \\
\hline UDP98-409 & $\begin{array}{l}\text { GCTGATGGGTTTTATGGTTTTC } \\
\text { CGGACTCTTATCCTCTATCAACA }\end{array}$ & $57^{\circ} \mathrm{C}$ & 74.51 & 79.51 & $\sim 129$ & \\
\hline
\end{tabular}




\begin{tabular}{|c|c|c|c|c|c|c|}
\hline Primer & Sequence (Forward and Reverse, $5^{\prime} \rightarrow 3^{\prime}$ ) & $\begin{array}{c}\text { Melting } \\
\text { Temperature }\end{array}$ & $\begin{array}{l}\text { Temperature } \\
\text { Principal Con } \\
\text { Lower Limit }\end{array}$ & $\begin{array}{l}\text { imization for } \\
\text { hent Analysis } \\
\text { Upper Limit }\end{array}$ & $\begin{array}{l}\text { Expected } \\
\text { Size (bp) }\end{array}$ & Reference \\
\hline UDP98-021 & $\begin{array}{l}\text { AAGCAGCAATTGGCAGAATC } \\
\text { GAATATGAGACGGTCCAGAAGC }\end{array}$ & $57^{\circ} \mathrm{C}$ & 72.0 & 82.04 & $\sim 145$ & Testolin et al., 2000 \\
\hline PS12A02 & $\begin{array}{l}\text { GCCACCAATGGTTCTTCC } \\
\text { AGCACCAGATGCACCTGA } \\
\end{array}$ & $60^{\circ} \mathrm{C}$ & 76.86 & 84.56 & $\sim 200$ & Downey \& Iezzoni, 2000 \\
\hline
\end{tabular}

\subsection{HRM-PCR amplification and Data Analysis}

Firstly, normalization the concentration of all the DNA samples was adjusted to $10 \mathrm{ng} / \mu \mathrm{l}$ before HRM analysis. HRM amplifications were performed on Rotor-Gene-Q 5 plex thermal cycler (Qiagen, Germany) with a 72-well carousel. The HRM mix was prepared as $10 \mu \mathrm{l}$ total volume consisting of $5 \mu \mathrm{l}$ Luminaris Colour HRM Master Mix (Thermo Scientific, USA), $0.5 \mu \mathrm{l}$ of $10 \mathrm{mM}$ each primer (Sentebiolab, Turkey), $10 \mathrm{ng}$ DNA, and nuclease-free water to $10 \mu \mathrm{l}$. We used a three-step cycling protocol as $95^{\circ} \mathrm{C} 10$ min initial denaturation followed by 45 cycles of $95^{\circ} \mathrm{C} 10 \mathrm{~s}$ denaturation, $60^{\circ} \mathrm{C} 30 \mathrm{~s}$ annealing, and $72^{\circ} \mathrm{C} 30 \mathrm{~s}$ extension. Data acquiesced following each extension step. We added $95^{\circ} \mathrm{C} 30 \mathrm{~s}$ and $50^{\circ} \mathrm{C} 30 \mathrm{~s}$ steps for heteroduplex formation to the end of the cycle. We performed HRM immediately after the amplification in increments of $0.1^{\circ} \mathrm{C} \mathrm{s}^{-1}$ hold time from $65^{\circ} \mathrm{C}$ to $95^{\circ} \mathrm{C}$ and data acquiesced continuously. All the reactions were performed as three replicates and no template control (NTC) was included in the reactions.

We analyzed the HRM data using both Rotor-GeneQ Software (2.3.5). We first normalized the HRM curves by removing the background fluorescence; then, drew difference plots of AS against the other cultivars for each SSR primer. Next, the software calculated Genotype Confidence Percentages (GCPs) for each cultivar against AS by setting each cultivar as "genotype". We set the confidence threshold to $90 \%$ for more reliable results.

\subsection{Developing $R$ Script for Principal Component Analysis of HRM data}

Although there is a well-developed R Script available for HRM-PCA analysis (Chou et al., 2020), we needed to improve it with different libraries to improve visualization performance. The improved script uses the new R Script to visualize the data by Principal Component Analysis (PCA) to be used to help distinguish the cultivars, which HRM failed. Following the HRM reaction, raw HRM temperature and normalized fluorescence data were exported with the Rotor-Gene-Q (2.3.5) software as comma-separated values (csv) file. Clustering and PCA were performed in RStudio (RStudio Team, 2020). The samples were clustered with 'mclust' (Scrucca et al., 2016) and visualized with 'ggplot2' (Wickham, 2016) packages. The script was improved by means of compatibility and better visualization by commonly used and recent packages. The PCA results can be exported as high-quality image formats as well as PDF for better publishing. We also added self-explanatory comments to the script in both English and Turkish to increase usability. The RStudio script is publicly available on GitHub (https://github.com/biologisthurkan/hrm_pca) and in Supplementary Material 1. The script can be used with all the HRM supported devices. A sample data file is also available on both GitHub and in Supplementary Material 2.

\section{Results}

\subsection{DNA extraction and PCR validation of SSR markers by Capillary Electrophoresis (CE)}

DNA extraction from each cultivar was successfully performed with the used protocol. The DNA concentration that was obtained varied between 39.32 to $95.06 \mathrm{ng}^{\mathrm{l}-1}$ and A260/230 ratio ranged from 1.234 to 1.766 , which is sufficient for HRM analysis. Each SSR marker successfully amplified for five studied apricot cultivars. The CE validation of the markers showed that each marker had different patterns among Turkish apricot cultivars. The PCR fragments sizes and counts generally varied among the cultivars (Table 2). The SSR markers pchgms4 and UDP96-001 amplified only one fragment for all the cultivars while the remaining markers amplified more than one fragment. The longest fragment (347 bp) was amplified by the UDP96-005 marker on KB and the shortest one (96 bp) was amplified by UDP96-010 on HB. According to the fragment sizes, the UDP96-001 marker could distinguish $\mathrm{AS}, \mathrm{HB}$, and $\mathrm{KB}$ but not $\mathrm{HH}$ and SK. We present an example CE comparison electropherogram for the pchgms 4 marker which compares the fragment peaks (Fig. 2). According to the peaks in Figure 2 and fragment data in Table 2, cultivars $\mathrm{HB}$ and $\mathrm{HH}$ have identical fragments (169 bp) and AS and SK also have identical fragments (194 bp). Therefore, based on CE results, the pchgms4 marker could not distinguish the cultivars $\mathrm{HB}$ and $\mathrm{HH}$, and AS and SK.

Table 2. SSR fragment analysis by capillary electrophoresis. Amplicon size of each primer per cultivars showed in the table. Cultivar abbreviations AS: Aprikoz Şalak, HB: Hasanbey, HH: Hacıhaliloğlu, KB: Kabaaşı, SK: Şekerpare.

\begin{tabular}{|c|c|c|c|c|c|}
\hline \multirow[b]{2}{*}{ Primer } & \multicolumn{5}{|c|}{ Amplicon sizes for each cultivar (bp) } \\
\hline & AS & $\mathrm{HB}$ & $\mathrm{HH}$ & $\mathrm{KB}$ & SK \\
\hline pchgms1 & 185 & $173,180,184,190$ & $180,189,193$ & $173,179,184,190$ & 180 \\
\hline pchgms2 & $159,170,172$ & $149,163,202$ & 191, 196 & $165,170,181$ & $158,169,172,176$ \\
\hline pchgms4 & 194 & 196 & 169 & 169 & 194 \\
\hline UDP96-001 & 137 & 133 & 135 & 198 & 135 \\
\hline UDP96-003 & 136 & 106 & $102,106,108,116,126$ & $103,136,147$ & 133 \\
\hline UDP96-005 & $139,144,150,156,158,162,167$ & $125,138,144,176$ & $125,138,143,149,178$ & $257,276,318,347$ & $126,159,164,177,179,182$ \\
\hline
\end{tabular}




\begin{tabular}{llllcc}
\hline & & \multicolumn{3}{c}{ Amplicon sizes for each cultivar (bp) } \\
Primer & AS & HB & HH & KB & SK \\
\hline UDP96-010 & $105,113,117,121$ & 96,105 & 98,105 & 107,114 & 14,105 \\
UDP97-402 & 146,152 & 168,173 & 164 & 165,170 & 165 \\
UDP98-406 & 107 & $100,105,117$ & $105,108,119$ & 104,108 & $107,119,123$ \\
UDP98-409 & $153,158,173,185,188$ & $168,173,182,187,190$ & $176,179,185,198,206$ & 223,227 & $117,138,143,147$ \\
UDP98-021 & 141,143 & 139,141 & 139,141 & 155,159 \\
PS12A02 & $173,184,187,193$ & $169,172,176,178$ & $168,179,182,188$ & $169,179,181,186$ & $176,181,187,193,196,199,201$ \\
\hline
\end{tabular}



Figure 2. Capillary Electrophoresis comparison electropherogram view of pchgms4 marker for five studied cultivars. Each cultivar is color-coded and peak sizes marked on each peak. Black dashed line represents the threshold for RFU signal.

\subsection{HRM Results}

The HRM analysis results of five closely related apricot cultivars scanned by 12 SSR markers are shown as difference plot curves (Fig. 3) and as GCP table (Table 3). The plot curves showed that 11 of the 12 SSR markers generated unique HRM curves for AS and distinguished it from the other cultivars. In a detailed look on the pchgms4 marker, which could not distinguish AS and SK cultivars according to the CE results, HRM curves of AS and SK differs from each other. The marker UDP96-001 generated almost identical curves for $\mathrm{AS}$ and $\mathrm{KB}$ and could not distinguish the cultivars. Auto calling function of the Rotor-Gene Q software calculates an R-value to provide a percentage of confidence. This percentage is used to call other genotypes as the positive control (AS in this study). The GCP lower than $90 \%$ were accepted as different genotypes while higher ones were accepted as the same genotype. The GCPs support the distinction among the five cultivars for 11 markers, except UDP96-001. The pchgms4 marker could clearly distinguish AS and SK from each other with 24.34 GCP. For the UDP96-001 marker, the GCP for KB was calculated as $99.73 \%$, which is quite higher than the $90 \%$ threshold and supports the plot curve result. Therefore, the UDP96-001 is indeed the only marker that could not distinguish AS from the others. The most distinguishing marker for AS was UDP98-409 based on GCPs.

Generally, HRM performed greater in the study. All the markers we tested except UDP96-001 generated unique melting shapes and this resulted in differentiation of the PDO cultivar. The marker pchgms4, which could not distinguish AS and SK by CE, worked much better on HRM analysis. HRM distinguished AS from SK with 24.34\% GCP (Table 3) and drew different melting shape (Fig. 3) even they generated identically sized fragments in CE results.

Table 3. Genotype distinguishing performance of each marker for five studied apricot cultivars. The confidence threshold is $90 \%$. Cultivar abbreviations AS: Aprikoz Şalak, HB: Hasanbey, HH: Hacıhaliloğlu, KB: Kabaaşı, SK: Şekerpare.

\begin{tabular}{|c|c|c|c|c|c|c|c|c|c|c|c|}
\hline \multicolumn{3}{|l|}{ pchgms1 } & \multicolumn{3}{|l|}{ pchgms2 } & \multicolumn{3}{|l|}{ pchgms4 } & \multicolumn{3}{|c|}{ UDP96-001 } \\
\hline Cultivar & Genotype & $\begin{array}{c}\text { Confidence } \\
\%\end{array}$ & Cultivar & Genotype & $\begin{array}{c}\text { Confidence } \\
\%\end{array}$ & Cultivar & Genotype & $\begin{array}{c}\text { Confidence } \\
\%\end{array}$ & Cultivar & Genotype & $\begin{array}{c}\text { Confidence } \\
\%\end{array}$ \\
\hline AS & AS & 100.00 & AS & AS & 100.00 & AS & AS & 100.00 & AS & AS & 100.00 \\
\hline $\mathrm{HB}$ & Variation & 32.72 & $\mathrm{HB}$ & Variation & 0.00 & $\mathrm{HB}$ & Variation & 15.25 & $\mathrm{HB}$ & Variation & 10.08 \\
\hline $\mathrm{HH}$ & Variation & 10.58 & $\mathrm{HH}$ & Variation & 0.06 & $\mathrm{HH}$ & Variation & 62.59 & $\mathrm{HH}$ & Variation & 76.60 \\
\hline KB & Variation & 72.04 & $\mathrm{~KB}$ & Variation & 0.01 & KB & Variation & 0.05 & $\mathrm{~KB}$ & AS & 99.73 \\
\hline SK & Variation & 3.38 & SK & Variation & 74.04 & SK & Variation & 24.34 & SK & Variation & 35.95 \\
\hline
\end{tabular}




\begin{tabular}{|c|c|c|c|c|c|c|c|c|c|c|c|}
\hline \multicolumn{3}{|c|}{ UDP96-003 } & \multicolumn{3}{|c|}{ UDP96-005 } & \multicolumn{3}{|c|}{ UDP96-010 } & \multicolumn{3}{|c|}{ UDP97-402 } \\
\hline Cultivar & Genotype & $\begin{array}{c}\text { Confidence } \\
\%\end{array}$ & Cultivar & Genotype & $\begin{array}{c}\text { Confidence } \\
\%\end{array}$ & Cultivar & Genotype & $\begin{array}{c}\text { Confidence } \\
\%\end{array}$ & Cultivar & Genotype & $\begin{array}{c}\text { Confidence } \\
\%\end{array}$ \\
\hline AS & AS & 100.00 & AS & AS & 100.00 & AS & AS & 100.00 & AS & AS & 100.00 \\
\hline $\mathrm{HB}$ & Variation & 51.62 & $\mathrm{HB}$ & Variation & 72.75 & НB & Variation & 31.64 & $\mathrm{HB}$ & Variation & 50.69 \\
\hline $\mathrm{HH}$ & Variation & 27.10 & $\mathrm{HH}$ & Variation & 22.19 & $\mathrm{HH}$ & Variation & 15.44 & $\mathrm{HH}$ & Variation & 19.31 \\
\hline KB & Variation & 8.06 & $\mathrm{~KB}$ & Variation & 46.00 & KB & Variation & 50.32 & KB & Variation & 18.03 \\
\hline SK & Variation & 6.43 & SK & Variation & 75.47 & SK & Variation & 38.35 & SK & Variation & 9.62 \\
\hline \multicolumn{3}{|c|}{ UDP98-406 } & \multicolumn{3}{|c|}{ UDP98-409 } & \multicolumn{3}{|c|}{ UDP98-021 } & \multicolumn{3}{|l|}{ PS12A02 } \\
\hline Cultivar & Genotype & $\begin{array}{c}\text { Confidence } \\
\%\end{array}$ & Cultivar & Genotype & $\begin{array}{c}\text { Confidence } \\
\%\end{array}$ & Cultivar & Genotype & $\begin{array}{c}\text { Confidence } \\
\%\end{array}$ & Cultivar & Genotype & $\begin{array}{c}\text { Confidence } \\
\%\end{array}$ \\
\hline AS & AS & 100.00 & AS & AS & 100.00 & AS & AS & 100.00 & AS & AS & 100.00 \\
\hline $\mathrm{HB}$ & Variation & 11.38 & HB & Variation & 4.80 & $\mathrm{HB}$ & Variation & 71.30 & HB & Variation & 72.15 \\
\hline $\mathrm{HH}$ & Variation & 64.33 & $\mathrm{HH}$ & Variation & 15.19 & $\mathrm{HH}$ & Variation & 22.45 & $\mathrm{HH}$ & Variation & 75.72 \\
\hline KB & Variation & 73.80 & KB & Variation & 4.75 & KB & Variation & 21.84 & KB & Variation & 66.76 \\
\hline SK & Variation & 68.16 & SK & Variation & 30.52 & SK & Variation & 0.63 & SK & Variation & 30.34 \\
\hline
\end{tabular}

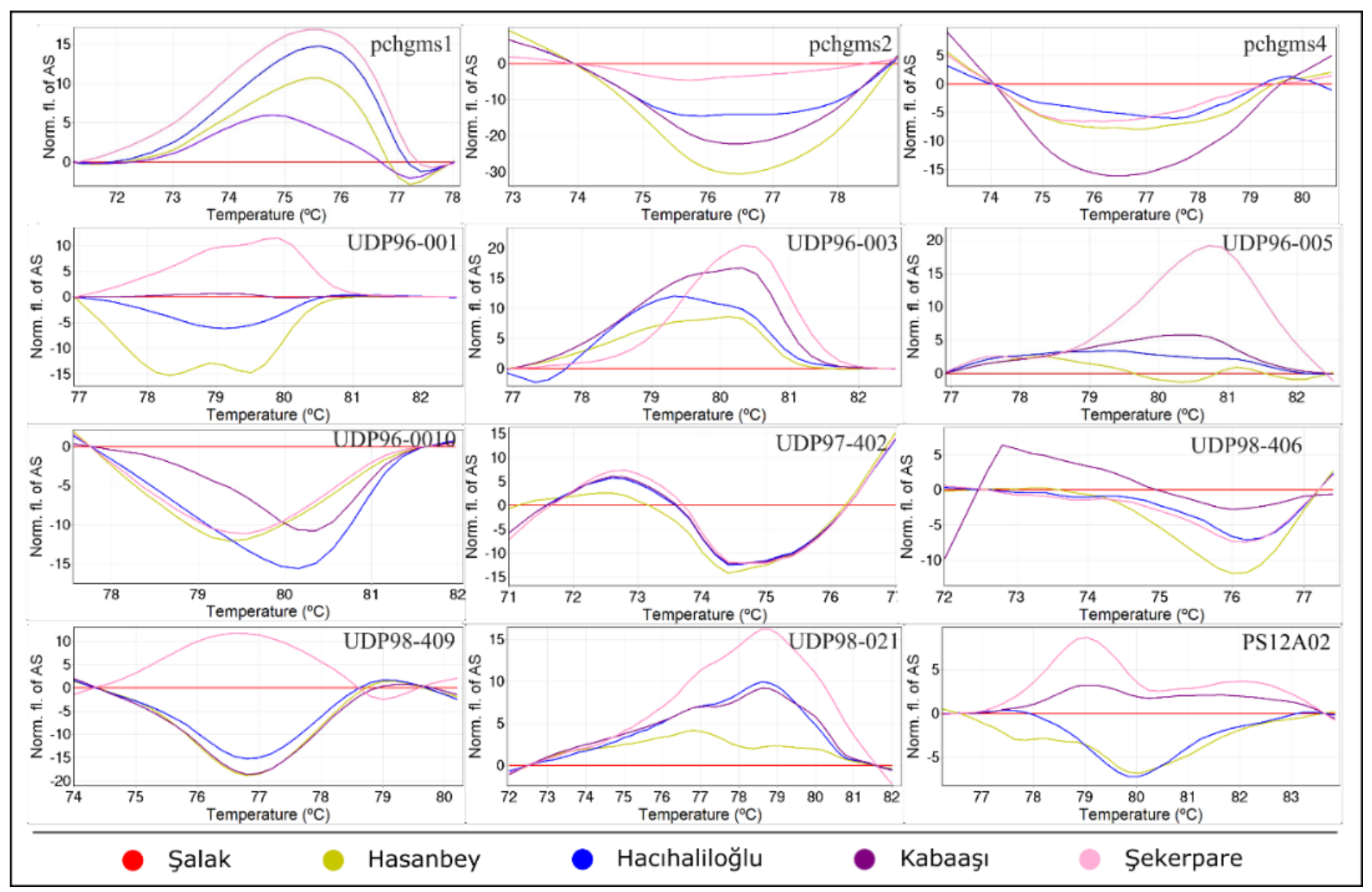

Figure 3. HRM analysis of five closely related apricot cultivars with 12 SSR marker. Difference plot curves were drawn based on AS cultivar.

To deeper analyze the HRM results, we used a third tool PCA clustering the data for failed marker UDP96-001. PCA could successfully cluster AS and $\mathrm{KB}$ and distinguished them (Fig. 4). According to the results, we were successfully able to distinguish the PDO AS apricot from closely related cultivars by HRM using 12 markers. Supporting HRM data with PCA resulted better resolution and distinguishing power.

\section{Discussion}

Distinguishing the special food products from closely related varieties is quite important due to high adulteration potential. "Iğdır Kayısısı" (Prunus armeniaca cv. Şalak) is a PDO product special to Iğdır region, which is the fifth ranking apricot producing region in Turkey (TÜİK, 2020). DNA based authentication methods are reliable and provide traceability. DNA barcoding, which uses the nucleotide sequences of short DNA fragments, is a gold standard to distinguish closely related species and reconstructing the phylogeny for many organism groups (Lahaye et al., 2008; Hollingsworth et al., 2011) particularly for animals and most plants (Pentinsaari et al., 2016). 
Nevertheless, it is not a convenient method for distinguishing at cultivar-level due to the slow mutation rate. Moreover, DNA barcoding requires experience in bioinformatics and specialization in computer software. SSR markers are more useful for screening genetic differences at the cultivar level since they are more stable and co-dominant transmission and conserved microsatellites are still widely used in taxonomy studies (Tuler et al., 2015). Due to those advantages, we combined the stability of SSR markers and distinguishing power of HRM on five closely related apricot cultivars including the PDO "Iğdır Kayısısı" with 12 potential SSR markers that were validated before for Prunus species and cultivars (Cipriani et al., 1999; Downey \& Iezzoni 2000; Testolin et al., 2000; Sosinski et al., 2000). This study is the first to use SSR-HRM to detect a PDO apricot and distinguish closely related apricot cultivars.

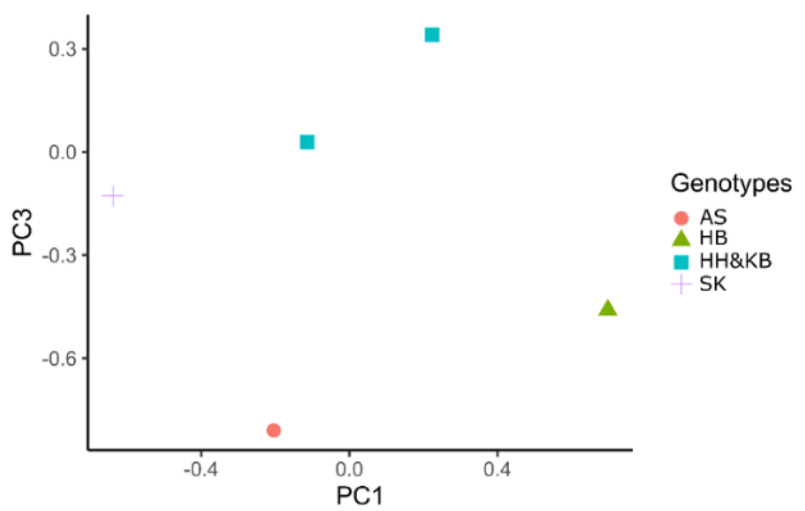

Figure 4. Principal Component Analysis, calculated by the $\mathrm{R}$ Script, for UDP96-001 marker distinguishes AS and KB cultivars.
We first validated the SSR markers whether they are successfully amplified on Prunus armeniaca cultivars by CE. The obtained fragment sizes are quite similar to the literature (Table 1 and Table 2) except for two markers. The primer pairs of the marker UDP97-402 amplified larger fragments than defined in the literature (expected: $~ 136$ bp,) for HB (168 and $173 \mathrm{bp}$ ), HH (164 bp), KB (165 and 170 $\mathrm{bp})$, and SK (165 bp) cultivars. The amplified fragments of the UDP98-409 marker ranging between 150 - 227 bp among cultivars were also larger than reported in the literature (expected fragment size $\sim 129 \mathrm{bp}$ ). Due to the nature of microsatellites, it varies by means of length due to repeating regions ( $\mathrm{Li}$ et al., 2018) thus, microsatellite markers could distinguish the species or cultivars. Although most of the markers generated different fragments for each cultivar, the pchgms 4 marker amplified identical fragments for AS and SK (194 bp), and HH and KB (169 bp). Therefore, even scanning by high resolution $\mathrm{CE}$, it is not possible to distinguish those cultivars. HRM generates melting curve shapes by continuously screening the level of fluorescence dye that intercalates with dsDNA during melting, the software can measure the distance between curves. The curve shapes depend on GC content, amplicon size, and the nucleotide sequence (Wittwer 2009). Thus, although the fragment sizes of AS and SK amplified by the primers of pchgms 4 marker are identical, different GC content or/and different nucleotide sequence separated AS and SK easily by HRM. HRM behaves quite different for the UDP96-001 marker. According to the CE results, the sizes of the fragments for AS (137 bp) and KB (198 bp) were different but HRM failed to distinguish those cultivars. We investigated the melting curve shape and determined that the shape is almost identical although the signal level is different (Fig. 5). Therefore, the failure of HRM might be because of the identical melting shape.

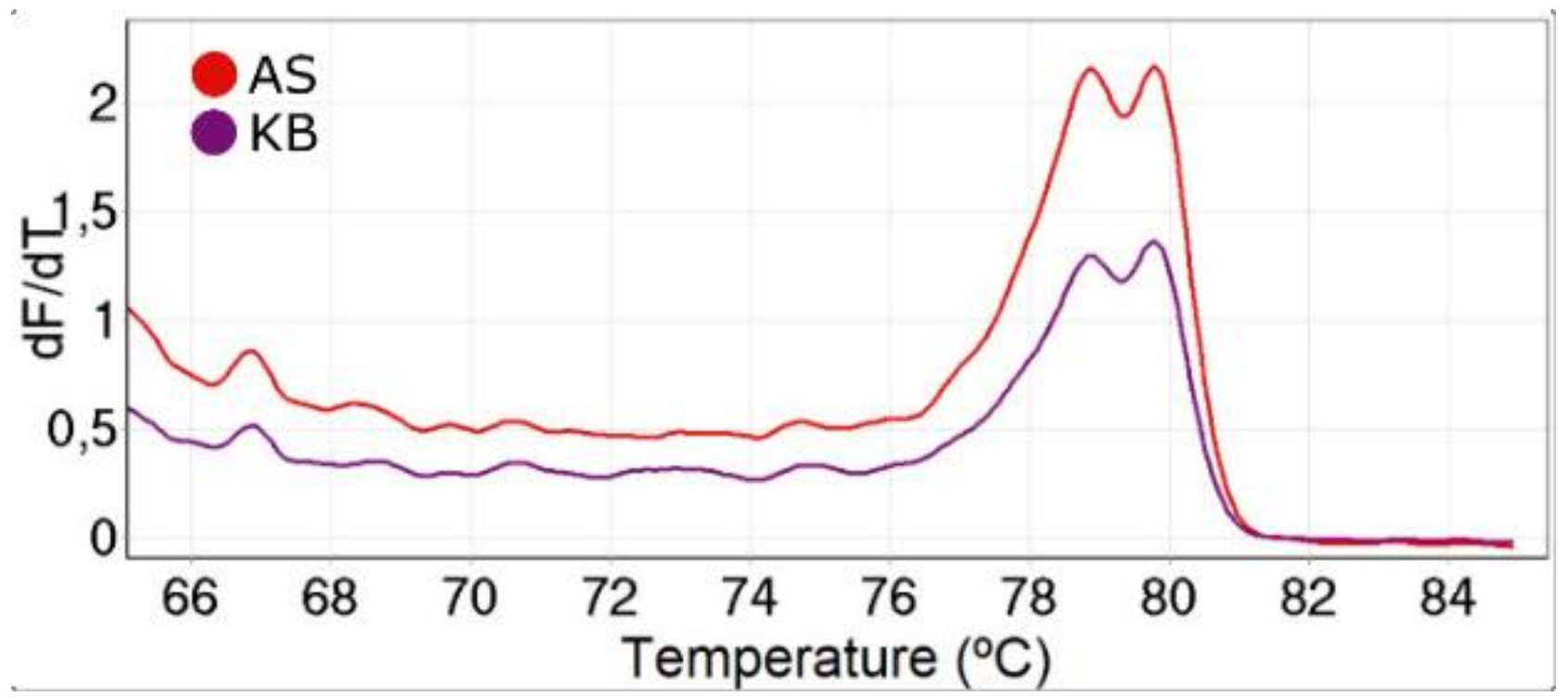

Figure 5. Melting Curve shapes of AS and KB cultivars.

New special food products, such as PDO products, bring new potential adulterants. Therefore, taking advantage of new molecular biology methods would help to manage food safety. In this study, we showed that HRM-SSR is a powerful approach for distinguishing closely related apricot cultivars. Moreover, when HRM failed, the raw HRM fluorescence data can be used on PCA for advanced analysis to distinguish the cultivars.
Acknowledgements: We thank Cemil ERNIM (Administrative and Technical Coordinator of Republic of Turkey Ministry of Agriculture and Forestry Apricot Research Institute) for sharing the apricot collection, Hakan DUMAN for developing the R Script for PCA analysis, Dr (PhD) Adnan AYDIN for his comments on capillary electrophoresis results, and anonymous referees for improvement of the manuscript. This work was financially supported by the Iğdır University Scientific Research Coordination Unit; Project number: 2019-FBE-A25. 
Ethics committee approval: Ethics committee approval is not required for this study.

Conflict of interest: The author declares that there is no conflict of interest.

\section{References}

Aydın, A., Ince, A. G., Uygur Gocer, E., \& Karaca, M. (2018). Single cotton seed DNA extraction without the use of enzymes and liquid nitrogen. Fresenius Environmental Bulletin, 27(10), 6722-6726.

Chou, L., Huang, S.J., Hsieh, C., Lu, M.T., Song, C.W., \& Hsu, F.C. (2020). A High Resolution Melting Analysis-Based Genotyping Toolkit for the Peach (Prunus persica) Chilling Requirement. International journal of molecular sciences, 21(4), 1543. https:// doi.org/10.3390/ijms21041543

Cipriani, G., Lot, G., Huang, W.G., Marrazzo, M.T., Peterlunger, E., \& Testolin, R. (1999). AC/GT and AG/CT microsatellite repeats in peach [Prunus persica (L) Batsch]: isolation, characterisation and cross-species amplification in Prunus. Theoretical and Applied Genetics, 99(1), 65-72. https://doi.org/10.1007/s001220051209

Downey, S.L., \& Iezzoni, A.F. (2000). Polymorphic DNA markers in black cherry (Prunus serotina) are identified using sequences from sweet cherry, peach, and sour cherry. Journal of the American Society for $\begin{array}{llr}\text { Horticultural } & \text { Science, } & \text { 125(1), }\end{array}$ https://doi.org/10.21273/JASHS.125.1.76

Druml, B., \& Cichna-Markl, M. (2014). High resolution melting (HRM) analysis of DNA-Its role and potential in food analysis. Food chemistry, $158,245-254$

Ercişli, S. (2004). A short review of the fruit germplasm resources of Turkey. Genetic Resources and Crop Evolution, 51(4), 419-435. https://doi.org/10.1023/B:GRES.0000023458.60138.79

FAOSTAT. (2020). Retrieved from http://www.fao.org/state-of-foodsecurity-nutrition

Ganopoulos, I., Argiriou, A., \& Tsaftaris, A. (2011). Microsatellite high resolution melting (SSR-HRM) analysis for authenticity testing of protected designation of origin (PDO) sweet cherry products. Food Control, 22(3-4), 532-541. https:// doi.org/10.1016/j.foodcont.2010.09.040

Hollingsworth, P.M., Graham, S.W., \& Little, D.P. (2011). Choosing and using a plant DNA barcode. PloS one, 6(5), e19254.

Lahaye, R., Van der Bank, M., Bogarin, D., Warner, J., Pupulin, F., Gigot, G., ... \& Savolainen, V. (2008). DNA barcoding the floras of biodiversity hotspots. Proceedings of the National Academy of Sciences, 105(8), 29232928.

Li, J., Xiong, C., He, X., Lu, Z., Zhang, X., Chen, X., \& Sun, W. (2018). Using SSR-HRM to identify closely related species in herbal medicine products: A case study on licorice. Frontiers in pharmacology, 9, 407. https://doi.org/10.3389/fphar.2018.00407

Osathanunkul, M., \& Madesis, P. (2019). Bar-HRM: a reliable and fast method for species identification of ginseng (Panax ginseng, Panax notoginseng, Talinum paniculatum and Phytolacca americana). PeerJ, 7, e7660. https:/ / doi.org/10.7717/peerj.7660

Passaro, M., Geuna, F., Bassi, D., \& Cirilli, M. (2017). Development of a highresolution melting approach for reliable and cost-effective genotyping of PPVres locus in apricot (P. armeniaca). Molecular Breeding, 37(6), 74. https://doi.org/10.1007/s11032-017-0666-0

Pentinsaari, M., Salmela, H., Mutanen, M., \& Roslin, T. (2016). Molecular evolution of a widely-adopted taxonomic marker (COI) across the animal tree of life. Scientific reports, 6(1), 1-12.

RStudio, Team. (2020). RStudio: Integrated Development for R. RStudio, PBC, Boston, MA. http://www.rstudio.com/

Scrucca, L., Fop, M., Murphy, T.B., \& Raftery, A.E. (2016). mclust 5: clustering, classification and density estimation using Gaussian finite mixture models. The R journal, 8(1), 289.

Sosinski, B., Gannavarapu, M., Hager, L.D., Beck, L.E., King, G.J., Ryder, C. D., ... \& Abbott, A.G. (2000). Characterization of microsatellite markers in peach [Prunus persica (L.) Batsch]. Theoretical and Applied Genetics, 101(3), 421-428. https://doi.org/10.1007/s001220051499

Testolin, R., Marrazzo, T., Cipriani, G., Quarta, R., Verde, I., Dettori, M.T., ... \& Sansavini, S. (2000). Microsatellite DNA in peach (Prunus persica L. Batsch) and its use in fingerprinting and testing the genetic origin of cultivars. Genome, 43(3), 512-520. https:/ / doi.org/10.1139/g00-010

Tindall, E.A., Petersen, D.C., Woodbridge, P., Schipany, K., \& Hayes, V.M. (2009). Assessing high-resolution melt curve analysis for accurate detection of gene variants in complex DNA fragments. Human mutation, 30(6), 876-883.
Tuler, A.C., Carrijo, T.T., Nóia, L.R., Ferreira, A., Peixoto, A.L., \& da Silva Ferreira, M.F. (2015). SSR markers: a tool for species identification in Psidium (Myrtaceae). Molecular Biology Reports, 42(11), 1501-1513.

TÜİK. (2020). Retrieved from http:// www.turkstat.gov.tr

Turkish Apricot Research Institute (2019). Retrieved from https://arastirma.tarimorman.gov.tr/kayisi/Menus/47/RegisteredCultivars

Wickham, H. (2016). ggplot2: Elegant Graphics for Data Analysis. SpringerVerlag New York. ISBN 978-3-319-24277-4 https://ggplot2.tidyverse.org

Wittwer, C.T. (2009). High-resolution DNA melting analysis: advancements and limitations. Human mutation, 30(6), 857-859. 